\title{
Estimation of the number of preventable COVID-19 deaths in relation to the restrictive measures adopted in America
}

José A. Cernuda-Martínez ${ }^{*}$ and Andrea Fernández-García²

${ }^{1}$ Universidad de Oviedo, Gijon Nursing Faculty, Gijon; ${ }^{2}$ Health Service, Principality of Asturias, Oviedo, Spain

\begin{abstract}
Introduction: In America, the United States was particularly affected by the COVID-19 pandemic. Objectives: To estimate how many daily COVID-19 deaths per 100,000 population would have been avoided if each one of five restrictive measures had been implemented at the time of diagnosis and to estimate a multiple linear regression model predictive of the number of deaths per 100,000 population based on the measures adopted by the countries. Methods: $A$ simple linear regression was performed between the days elapsed since the first COVID-19 diagnosed case and the implementation of each one of the five restrictive measures by the 27 American countries studied and the number of COVID-19 deaths per 100,000 population. Results: For each day between the first COVID-19 reported case and the adoption of restrictive measures, between 0.250 $(p=0.021)$ and $0.600(p=0.001)$ patients per 100,000 population died, depending on the measure in question. Conclusions: Adoption of restrictive measures and social distancing are necessary for reducing the number of people infected with COVID-19 and their mortality. In addition, promptness of their establishment is essential in order to reduce the number of deaths.
\end{abstract}

KEY WORDS: COVID-19. Mortality. Public health.

\section{Estimación del número de muertes evitables por COVID-19 en relación con las medidas restrictivas adoptadas en América}

\section{Resumen}

Introducción: En América, Estados Unidos se vio particularmente afectado por la pandemia de COVID-19. Objetivos: Estimar cuántas muertes diarias por COVID-19 por 100000 habitantes se hubiesen evitado si cada una de las cinco medidas restrictivas se hubiera implementado en el momento del diagnóstico, así como estimar un modelo de regresión lineal múltiple predictivo del número de muertes por 100000 habitantes basado en las medidas adoptadas por los países. Métodos: Se realizó una regresión lineal simple entre los días transcurridos desde el primer caso diagnosticado de COVID-19 y la implantación de cada una de las cinco medidas restrictivas llevadas a cabo por los 27 países americanos estudiados y el número de muertes por COVID-19 por cada 100000 habitantes. Resultados: Por cada día entre el primer caso reportado de COVID-19 y la adopción de medidas restrictivas, fallecieron entre $0.250(p=0.021)$ y $0.600(p=0.001)$ pacientes por cada 100000 habitantes, dependiendo de la medida en cuestión. Conclusiones: La adopción de medidas restrictivas y la distancia social son necesarias para reducir el número de personas infectadas con COVID-19 y su mortalidad; además, la velocidad de su establecimiento es esencial para reducir el número de muertes.

PALABRAS CLAVE: COVID-19. Mortalidad. Salud pública.

Correspondence:

*José A. Cernuda-Martínez

E-mail: jacernudam@gmail.com
Gac Med Mex. 2021;157:225-230

Contents available at PubMed

www.gacetamedicademexico.com

0016-3813/@ 2020 Academia Nacional de Medicina de México, A.C.. Published by Permanyer. This is an open access article under the CC BY-NC-ND license (http://creativecommons.org/licenses/by-nc-nd/4.0/). 


\section{Introduction}

In December 2019, a new coronavirus emerged in Wuhan, China, which has become a global health problem: ${ }^{1}$ SARS-CoV-2, which causes COVID-19, and that belongs to the same family as SARS and Middle East respiratory syndrome coronavirus (MERS-CoV); all of them cause zoonotic infections. ${ }^{2}$

America has been specially affected by the COVID-19 pandemic. Eight countries (Ecuador, Brazil, Peru, Panama, Chile, Mexico, Canada, and the United States) are among the 20 nations with the highest COVID-19 mortality per 100,000 population. ${ }^{3-9}$ Currently, there is no specific treatment available, and if that weren't enough, there are notorious deficiencies in health systems and infrastructure in Latin America, especially in beds at intensive care units and mechanical ventilators required for the support of patients with severe infection, so that the risk of an overwhelming increase in the number of deaths is latent. ${ }^{9-12}$

This makes non-pharmacological interventions essential for reducing morbidity and mortality. These interventions have been shown to be effective ways to respond to the outbreak when early implemented in the epidemic. ${ }^{13-15}$ Three important non-pharmacological interventions were carried out in China to control the spread and reduce the size of the COVID-19 outbreak: ${ }^{10}$

- First, inter-city travel bans and establishment of a cordon sanitaire in Wuhan and surrounding cities of the Hubei province. 10,12,14

- In the second place, measures to improve detection, contact tracing, identification, diagnosis, isolation and reporting of people suspected of having the disease and confirmed cases..$^{10,15}$

- Thirdly, travel and contact restrictions, which included limiting individual social contact, use of personal hygiene and protective measures, and increasing physical distance between COVID-19 patients and those who have not become infected. ${ }^{10,16}$

The purposes of this study were the following:

- To estimate how many daily deaths per 100,000 population could have been avoided if each analyzed non-pharmacological measure would have been taken at the time the first case was diagnosed.

- To estimate a multiple linear regression model predictive of the number of deaths per 100,000 population based on the measures adopted by the countries.

\section{Methods}

An ecological study was designed in July 2020 on 27 American countries. The inclusion criterion was having access to the data of all implemented measures that were included in the study. The starting point was established as the date of the first COVID-19 official diagnosis, ${ }^{17}$ with the days elapsed from its occurrence to the implementation of five measures being quantified; said measures were regarded as independent variables: ${ }^{17}$

- Days between first case and non-essential workplaces total closure.

- Days between first case and ban on arrival of international travelers or border closure.

- Days between first case and public events prohibition.

- Days between first case and face-to-face classes suspension.

- Days between first case and prohibition to leave home.

COVID-19 death rate per 100,000 population for each of the 27 countries was obtained up to July 9 , $2020^{18}$ (dependent variable), as well as the number of hospital beds and doctors per 1,000 population. ${ }^{19}$

\section{Statistical analysis}

A simple linear regression was carried out between each independent variable and the dependent variable in order to find out the number of deaths per 100,000 population that could have been avoided each day if each one of the measures would have been adopted at the time the first case was diagnosed.

A multiple linear regression predictive model was estimated between the number of deaths per 100,000 population (dependent variable) and the "days between first case and prohibition to leave home" independent variable. This model was adjusted for the other independent variables by selecting the best model based on all equations. To choose the final model, Mallows's Cp criterion was used, with the model with the lowest value being selected.

A level of significance with a $p$-value $<0.05$ and a $95 \%$ confidence index were considered. For reliability of the model to be externally assessed, prediction loss was examined using the shrinkage method, which consists of calculating the difference between the square of the multiple correlation coefficient of the model estimated in the derivation group $\left(R^{2}\right)$ and the 
square of the simple correlation coefficient between the predicted value with the model estimated in the derivation group and the dependent variable $(\mathrm{Y})$, calculated in the validation group $\left(\mathrm{r}^{2}\right)$. A difference lower than or equal to 0.1 was assumed to be acceptable.

Analyses were carried out with the Stata 15 statistical software package.

\section{Results}

Table 1 shows, for each of the 27 countries, the date the first official COVID-19 diagnosis took place, the days elapsed until the implementation of each one of the five restrictive measures, the number of COVID-19 deaths per 100,000 population and the number of hospital beds and resources available per 1,000 population in the analyzed countries.

Table 2 shows the $\beta$-coefficient obtained after the linear regression between the independent variable and each one of the dependent variables. Each $\beta$-coefficient expresses the number of daily deaths per 100,000 population that would have been avoided if each preventive measure would have been adopted the day of the first COVID-19 diagnosis.

Table 3 shows the variables included in the predictive model, as well as their $95 \%$ confidence intervals and p-values. Mallows's Cp-value was 2.03; adjusted $R^{2}$ value was 0.391 and the prediction loss value (difference between $R^{2}$ and $r^{2}$ or shrinkage) was -1.235 $\times 10^{-8}$.

\section{Discussion}

The purpose of this study was to estimate how many daily COVID-19 deaths per 100,000 population could have been avoided if each one of the five restrictive measures would have been taken at the time the first case was diagnosed. According to the results of this study, failure to adopt each one of these measures would cause an increase of between 0.250 and 0.600 deaths per 100,000 population/day for every 24 hours of delay in their implementation since the first case official diagnosis. This number of preventable deaths was statistically significant with four of the five established measures.

The Imperial College London showed that a combination of case isolation and voluntary quarantine for three months might prevent $31 \%$ of deaths, in comparison with an epidemic without any control measures. Adding social distancing of people aged 70 and older for four months would increase the proportion of prevented deaths to $49 \%$. The combination of case isolation, home quarantine, social distancing of the entire population, and closure of schools and universities was considered to be the most effective combination to reduce the reproduction number to a value close to one. ${ }^{20}$ Although more comprehensive and stringent prevention and control measures are more effective for COVID-19 containment, at some point the incremental effect of adding another restrictive measure is only minimal and should be weighed against negative collateral effects, such as social and economic consequences for communities that have been subjected to the measures for prolonged periods, which could also lead to an increased burden on health in general. ${ }^{21}$

Assuming that strict distancing and confinement measures contribute to a decrease in the number of cases and, consequently, of deaths, the following steps will be directed at how to de-escalate imposed restrictive measures. If due to the enormous social and economic costs of confinement the quarantine was prematurely terminated, a return to the initial scenario would occur, where the epidemic spreads again, and exponentially. ${ }^{15}$ The model developed by Prem ${ }^{15}$ suggests that sudden lifting of interventions might lead to an earlier secondary peak, which could be prevented by gradually relaxing the interventions. In this sense, Colburn ${ }^{22}$ suggests that, to prevent health system overload, testing, contact tracing and quarantine of suspected cases could be the main strategies after drastic social distancing non-pharmacological interventions relaxation. Colburn ${ }^{22}$ suggests incorporating these strategies into models that allow countries to have higher testing capacity in order to decide whether said policies could be successful in suppressing the spread of COVID-19 in a particular nation.

Non-pharmacological interventions also have adverse effects on individuals, communities, and national economy. Some studies concluded that the quarantine might have harmful psychological effects, such as post-traumatic stress symptoms, confusion, and anger, which can lead to long-term psychological adverse effects. ${ }^{23}$

This study has the limitations inherent to ecological studies, including the so-called "ecological fallacy". This determines that, since the groups of subjects are not homogeneous in terms of exposure, causal inferences are limited by the association that takes place in the group rather than in the individual, i.e., extrapolating data from the population to the individual is incorrect. Other limitations include multicollinearity (it 


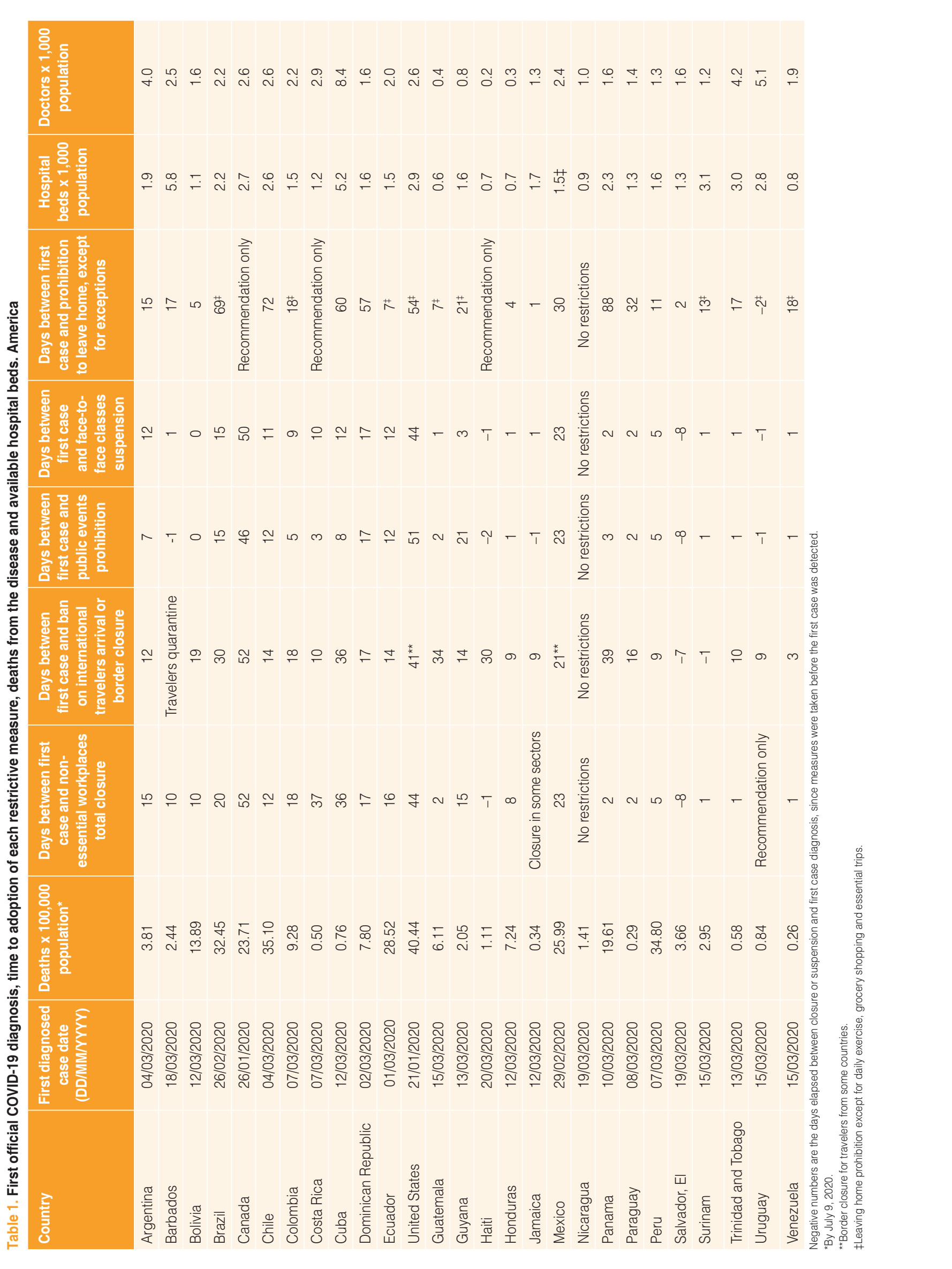


Table 2. Simple linear regression $\beta$-coefficients between each independent variable and the dependent variable (deaths per 100,000 population)

\begin{tabular}{|c|c|c|c|c|}
\hline \multirow[t]{2}{*}{ Independent variable } & \multirow{2}{*}{$\beta$-coefficient } & \multicolumn{2}{|c|}{$95 \% \mathrm{Cl}$} & \multirow{2}{*}{ p-value } \\
\hline & & Lower limit & Upper limit & \\
\hline Days between first case and non-essential workplaces total closure & 0.324 & -0.043 & 0.691 & 0.081 \\
\hline Days between first case and ban on international travelers arrival or border closure & 0.382 & 0.001 & 0.762 & $0.049^{*}$ \\
\hline Days between first case and public events prohibition & 0.593 & 0.268 & 0.918 & $0.001^{*}$ \\
\hline Days between first case and face-to-face classes suspension & 0.600 & 0.258 & 0.942 & $0.001^{*}$ \\
\hline Days between first case and prohibition to leave home & 0.250 & 0.041 & 0.458 & $0.021^{*}$ \\
\hline
\end{tabular}

*Statistically significant value.

Table 3. Estimated model variable coefficients, with their respective $95 \%$ confidence intervals and p-values

\begin{tabular}{l|c|c|c|c|}
\hline Independent variable included/model constant & $\beta$-coefficient & \multicolumn{2}{|c|}{$95 \%$ Cl } \\
\cline { 2 - 4 } & & & Lower limit & Upper limit \\
\hline Constant & 7.300 & -0.865 & 15.465 \\
\hline Days between first case and prohibition to leave home & 0.117 & -0.101 & 0.334 \\
\hline Days between first case and non-essential workplaces complete closure & -0.582 & -1.422 & 0.273 \\
\hline Days between first case and face-to-face classes suspension & 1.300 & 0.261 & 2.158 & 0.162 \\
\hline *Statistically significant value & & & $0.015^{*}$ \\
\hline
\end{tabular}

*Statistically significant value.

is difficult for the observed effects of two or more variables to be separated) and temporal ambiguity.

\section{Conclusions}

Adoption of restrictive measures and social distancing is necessary for accomplishing a decrease in the number of people infected with COVID-19 and, consequently, in mortality figures. In addition, promptness of their establishment is essential for decreasing the number of deaths. The need for a well-endowed health system in terms of quality and quantity, as well as all possible human and material resources should be added in order to give a forceful response to the pandemic caused by SARS-CoV-2.

\section{Conflict of interests}

The authors declare that they have no conflicts of interest.

\section{Funding}

The authors did not receive any sponsoring to carry out this article.

\section{Ethical disclosures}

Protection of human and animal subjects. The authors declare that no experiments were performed on humans or animals for this research.

Confidentiality of data. The authors declare that no patient data appear in this article.

Right to privacy and informed consent. The authors declare that no patient data appear in this article.

\section{References}

1. Zhu N, Zhang D, Wang W, Li X, Yang B, Song J, et al. A novel coronavirus from patients with pneumonia in China, 2019. N Engl J Med. 2020:382:727-733.

2. Ji W, Wang W, Zhao X, Zai J, Li X. Cross-species transmission of the newly identified coronavirus 2019-nCoV. J Med Virol. 2020;92:433-440.

3. Burki T. COVID-19 in Latin America. Lancet Infect Dis. 2020:20:547-548.

4. Cimerman S, Chebabo A, Cunha CAD, Rodríguez-Morales AJ. Deep impact of COVID-19 in the healthcare of Latin America: the case of Brazil. Braz J Infect Dis. 2020;24:93-95.

5. De Freitas e Silva R. What are the factors influencing the COVID-19 outbreak in Latin America? Travel Med Infect Dis. 2020;35:101667.

6. Miller MJ, Loaiza JR, Takyar A, Gilman RH. COVID-19 in Latin America: novel transmission dynamics for a global pandemic? PLoS Negl Trop Dis. 2020;14:e0008265.

7. Navarro JC, Arrivillaga-Henríquez J, Salazar-Loor J, Rodríguez-Morales AJ. COVID-19 and dengue, co-epidemics in Ecuador and other countries in Latin America: Pushing strained health care systems over the edge. Travel Med Infect Dis. 2020;37:101656.

8. Sánchez-Duque JA, Arce-Villalobos LR, Rodríguez-Morales AJ. Coronavirus disease 2019 (COVID-19) in Latin America: role of primary care in preparedness and response. Aten Primaria. 2020;52:369-372. 
9. González-Jaramillo V, González-Jaramillo N, Gómez-Restrepo C, Palacio-Acosta CA, Gómez-López A, Franco OH. Proyecciones de impacto de la pandemia COVID-19 en la población colombiana, según medidas de mitigación. Datos preliminares de modelos epidemiológicos para el periodo del 18 de marzo al 18 de abril de 2020. Rev Salud Publica. 2020;202:1-6.

10. Dunlop C, Howe A, Li D, Allen LN. The coronavirus outbreak: The central role of primary care in emergency preparedness and response. BJGP Open. 2020;4:bjgpopen20X101041

11. Rodríguez-Morales AJ, Sánchez-Duque JA, Hernández-Botero S, Pérez-Díaz CE, Villamil-Gómez WE, Méndez CA, et al. Preparation and control of the coronavirus disease 2019 (COVID-19) in Latin America. Acta Med Peru. 2020;37:3-7.

12. Dong EH, Du H, Gardner DL. An interactive web-based dashboard to track COVID-19 in real time. Lancet Infect Dis. 2020;20:533-534.

13. Anderson RM, Heesterbeek H, Klinkenberg D, Hollingsworth TD. How will country-based mitigation measures influence the course of the $\mathrm{CO}$ VID-19 epidemic? Lancet. 2020;395:931-934.

14. Lau H, Khosrawipour V, Kocbach P, Mikolajczyk A, Schubert J, Bania J, et al. The positive impact of lockdown in Wuhan on containing the COVID-19 outbreak in China. J Travel Med. 2020;27:taaa037.

15. Prem K, Liu Y, Russell T, Kucharski AJ, Eggo RM, Davies N. The effect of control strategies that reduce social mixing on outcomes of the COVID-19 epidemic in Wuhan, China: a modelling study. Lancet Public Health. 2020;5:261-270.
16. Chen W, Wang Q, Li YQ, Yu HL, Xia YY, Zhang ML, et al. Early containment strategies and core measures for prevention and control of novel coronavirus pneumonia in China. Zhonghua Yu Fang Yi Xue Za Zhi. 2020:54:239-244.

17. University of Oxford [Internet]. United Kingdom: Oxford Covid-19 Government Response Tracker; 2020.

18. Johns Hopkins University of Medicine. [Internet]. USA: Coronavirus Resource Center. Mortality analyses; 2020.

19. Banco Mundial [Internet]. Médicos (por cada 1,000 personas); 2020

20. Ferguson NM, Laydon D, Nedjati-Gilani G, Imai N, Ainslie K, Baguelin M, et al. Report 9-Impact of non-pharmaceutical interventions (NPIs) to reduce COVID-19 mortality and healthcare demand. London: Imperial College London; 2020.

21. Nussbaumer-Streit B, Mayr V, Dobrescu Al, Chapman A, Persad E, Klerings I, et al. Quarantine alone or in combination with other public health measures to control COVID-19: a rapid review. Cochrane Database Syst Rev. 2020;2020;4:CD013574.

22. Colbourn T. COVID19: extending or relaxing distancing control measures. Lancet Public Health. 2020;5:e236-e237.

23. Brooks SK, Webster RW, Smith LE, Woodland L, Wessely S, Greenberg N, et al. The psychological impact of quarantine and how to reduce it: rapid review of the evidence. Lancet. 2020; 395:912-920. 